\section{International Journal of Current Research in Medical Sciences}

ISSN: 2454-5716

www.ijcrims.com

Volume 2, Issue 11 -2016

\title{
The nature of institution and the prevalence of scabies: a case study of inmates of Portharcourt prison of rivers state Nigeria.
}

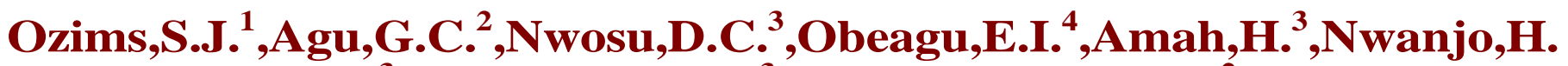 \\ $\mathrm{U}^{3}$, Edward, Amaka ${ }^{3}$ and Izuchukwu,I.F. ${ }^{2}$
}

1.Department of Public Health Sciences, Faculty of Health Sciences, Imo State University, Owerri.

2.Department of Optometry, Faculty of Health Sciences, Imo State University, Owerri.

3.Department of Medical Laboratory Science, Faculty of Health Sciences, Imo State University, Owerri.

4.Diagnostic Laboratory Unit, Department of Health Services, Michael OKpara University of Agriculture, UMudike, Abia State, Nigeria.

\section{Abstract}

The study examined the nature of institution and the prevalence of scabies among inmates of Portharcourt Prison Rivers State.In pursuance to this, a sample of three hundred and forty eight (348) respondents was drawn from Ire entire inmates population. A descriptive cross sectional method was adopted. Four hypotheses were adopted. Questionnaire and observation method were used to obtain the much needed data. Data collected via questionnaire were analysed using frequency tables, pie chart, bar chart and histogram. The adopted hypotheses were tested using chi-square. The study identified the low level of knowledge on scabies among inmates, the restricted nature of Portharcourt prison, the culture of self care among inmates and more importantly the overcrowded nature of Portharcourt prison as factors behind the prevalence of scabies in the prison. It was therefore recommended among others that health education in Nigerian prisons should be increased,more so as it has to do with the aetiology of scabies. Concerted efforts should be made to decongest Nigerian prisons. An effective disease surveillance mechanism should be introduced in Nigerian prisons.

Keywords: Prevalence, Scabies, Inmates Portharcourt Prison,

\section{Introduction}

Human scabies is a parasitic infestation of the skin caused by "Sacoptes scabiei var horn in is", The mite barely visible to the naked eye burrows into the epidermis and lays eggs triggering a host immune response that leads to intense itching in response to just a few mites. Scabies infestation is frequently complicated by bacterial infection, leading to the development of skin sores that in turn can cause more serious consequences such as septicaemia, heart disease and chronic kidney disease. 
Int. J. Curr. Res. Med. Sci. (2016). 2(11): 11-26

Scabies is a worldwide public health problem affecting people of all ages, races and socioeconomic groups. Overcrowding, delayed diagnosis and treatment and poor public education contribute to the prevalence of scabies in both industrialised and non industrialised nations. Prevalence rates are higher in children and people who are sexually active (Sergio, 2008).

It is about $0.35 \mathrm{~mm}$ long. The female mite tunnels into the epidermis and deposits eggs along the burrow. The larvae hatch in a few days and create new burrows. Development from egg to adult takes about 10-15 days. Mites die after 4-6 weeks. An average host harbours ten mites but this may greatly increase in immunocompromised patients (Tidy, 2013).

Classical scabies is transmitted only via direct skin contact. Scabies epidermics usually occur in institutional settings or in socially deprived groups. The more crowded the living conditions, the higher the prevalence of scabies the population.

Scabies is one of the commonest dermatological conditions, accounting for a substantial proportion of disease in developing countries. Globally, it affects more than 130 million people at any time. Rates of scabies occurrence vary in the recent literature from $0.3 \%$ to $46 \%$ International Alliance for the Control of Scabies, 2014). In the developed world, outbreaks in health institutions and vulnerable communities contribute to significant economic cost in national health services. However, in resource poor tropical settings, the sheer burden of scabies infestation as well as their complications imposes a major cost on health care systems. In 2010, it was estimated that the direct effects of scabies infestation on the skin alone led to than 1.5 million YLDS (Years lived with disability) and the indirect effects of complications on renal and cardiovascular function are far greater (IACS, 2014).

Scabies affects people from every country. However, it is the most vulnerable, young children and the elderly in resource poor communities who are especially susceptible to scabies as well as to the secondary complications of infestations. The highest rates occur in countries with hot, tropical climates where infestation is endemic especially in communities where overcrowding and poverty coexist.

The nature of prison as an institution and the prevalence of scabies have remained a major problem ravaging Port Harcourt prison. Nigerian prison system dates as far back as 1872 when the British Colonialist established the first prison in the country and was situated at Broad Street Lagos otherwise known as Broad Street Prison, The prison started with a capacity of 300 inmates. Then the inmates were made to engage in manual labour in service of the colonial administration and these were naturally no special trained prison staff. However, from 1872 to 1910 more other prisons were established in Calabar, Sapele, Degema, Jebba, Onitsha, Lokoja, Benin and Ibadan.

According to the Prison Act, Cap 366 Laws of the Federation of Nigeria 1990, a prison is a place delimited and declared as such by the law of the state and created to ensure restraint and custody of individuals accused or convicted of violating the criminal laws of the state. The mission of Nigerian Prison System is to promote public protection by providing assistance for offenders in their Deformation and rehabilitation under safe, secure and humane standards and to facilitate their social reintegration into society.

According to Wolpe cited in Uwaneme (2011), Bundu and Port Harcourt prison ground claimed ownership of various areas of the town. But with the advent of Europeans in the 20th century, the city of Port Harcourt changed. The white man like the other areas colonised and established the church, school and trade relations for these institutions to thrive. The white man also instituted a penal institution to restrain the primitive, unsocialised sacrifices as well as hostility to the whites with forced labor from Owerri, Ikot ekpene and Ikwerre of the Rivers State, the Port Harcourt and which then was almost a forest was cleared. 
Int. J. Curr. Res. Med. Sci. (2016). 2(11): 11-26

\section{Aim of the Study}

The broad objective of the study is to ascertain how the nature of Port Harcourt prison institution relate to the prevalence of scabies among inmates. The specific objectives include:

(i) To examine the incidence and prevalence of scabies in Port Harcourt prison.

(ii) To identify the level of knowledge of inmates in Port Harcourt prison.

iii) To examine the relationship between the nature of prison and the prevalence of scabies among inmates of Port Harcourt prison.

(iv) To make recommendations on how to check the occurrence/spread of scabies in Port Harcourt prison. Research Questions

The research study is structured to answer the following questions:

i) What is the level of knowledge of inmates, of Port Harcourt prison on scabies?

ii) What are the causes of scabies among inmates of Port Harcourt prison?

(iii) What is the relationship between nature of prison and prevalence of scabies among inmates of Port Harcourt prison?

(iv) What necessary measures are required to make the prison scabies free?

\section{Methodology}

\section{Population of Study}

The institution has an estimated population of two thousand six hundred and eighty eight (2688) prisoners. Of this population, two thousand six hundred and thirty (2630) are males while fifty eighty (58) are females.

\section{Sample Size}

A sample of three hundred and forty eight (348) inmates was drawn for this study. The sample was determined using Yaro Yemene's formular is shown below

$$
\begin{aligned}
\mathrm{n}= & \mathrm{N} \\
& 1+\mathrm{N}(\mathrm{e}) 2
\end{aligned}
$$

Where

$\begin{array}{lll}\mathrm{n} & =\text { sample size } \\ \mathrm{e} & = & \text { Error of tolerance } \\ \mathrm{N} & = & \text { population } \\ \mathrm{I} & = & \text { Constant } \\ \text { Hence, } & \\ \mathrm{n} & = & ? \\ \mathrm{~N} & = & 2688 \\ \mathrm{e} & = & 5 \%(0.05)\end{array}$

Substituting the formular,

$$
\begin{array}{lll}
\mathrm{N} & =\frac{2688}{1+2688(0.05) 2} \\
& =\frac{2688}{1+2688(0.0025)} \\
= & \frac{2688}{1+6.72} & \\
=\quad \frac{2688}{7.72} & \\
= & 348
\end{array}
$$

Sampling Techniques

Convenience random sampling procedure was adopted for this study. Convenience random sampling involves the researchers obtaining response from members of the target population that are willing to oblige him. Hence, prison inmates who were busy or unwilling to participate in the study were neither persuaded nor coerced to get involve.

\section{Instrument of Data Collection}

Useful data for the work was obtained via primary and secondary data sources.

The primary data sources employed in the work are the questionnaire and observation.

Questionnaire:

A questionnaire is a list of questions to be asked by the researcher. It is prepared in such a manner that the questions are asked in exactly the same way to every respondent (Me Neill cited in Okereke 2003). The questions were formulated in line with the research objectives.

The questionnaire has two parts A and B. Section A consist of the respondents demographic characteristics. 
Section B contains items designed to elicit response in the nature of Port Harcourt prison and prevalence of scabies among inmates.

Observation (Non Participant):

According to Aimakho (2010), observation is a research strategy which aims to gain a close and intimate familiarity with a given area of study through an intensive involvement with people in their environment. Observational method of research involves the planned watching, recording and analysis of observed behaviour as it occurs in a natural setting (Keegan, 2007).

The researchers hence had the opportunity to observe realities within the environment. Events were recorded as they unfold.

Validity of Research Instrument

The research was conducted in such a manner that the validity of the main research instrument is not in doubt. The research instrument (questionnaire) was given to my supervisor for scrutiny. The aim was primarily to measure face and content validity.

Reliability of the Research Instrument
In a bid to establish the reliability of the research instrument, the researchers gave the questionnaire to the respondents and had their result.They selected few of the respondents and gave them the questionnaires again and they still gave the same result with the repeated test. This shows the reliability of the instrument. Method of Data Analysis

Data collected from the questionnaire was analysed using frequency tables and charts. The adopted hypotheses were tested using chi square (X2) technique.

The application of these statistical techniques enabled the researcher to convert data into empirical figures, test their validity and analyse the result.

\section{Administration of Research Instrument}

The research instrument (questionnaire) was personally administered to the respondents by the researchers. The literate respondents were given the leeway to fill the questionnaires which were collected on the spot. The researchers however, took time to explain the contents of the questionnaire to the illiterate respondents. The responses of such illiterate respondents were filled by the researcher accordingly.

\section{Results}

TABLE 1: Distribution of Respondents by Sex.

\begin{tabular}{|l|l|l|}
\hline sex & RESPONDENTS & PERCENTAGE \\
\hline Kale & 327 & $94 \%$ \\
\hline Female & 21 & $6 \%$ \\
\hline total & 348 & $100 \%$ \\
\hline
\end{tabular}

The table above showed that out of the total number of the respondents, 327 (94\%) were males while $21(6 \%)$ werefemales. 
TABLE 2: Distribution of Respondents by Age.

\begin{tabular}{|l|l|l|}
\hline AGE & RESPONDENTS & PERCENTAGE \\
\hline $15-19 \mathrm{yrs}$ & 30 & $8.6 \%$ \\
\hline $20-24 \mathrm{yrs}$ & 39 & $11.2 \%$ \\
\hline $25-29 \mathrm{yrs}$ & 46 & $13.2 \%$ \\
\hline $30-34 \mathrm{yrs}$ & 67 & $19.3 \%$ \\
\hline $35-39 \mathrm{yrs}$ & 59 & $17.0 \%$ \\
\hline $40-44 \mathrm{yrs}$ & 38 & $10.9 \%$ \\
\hline $45-49 \mathrm{yrs}$ & 42 & $12.0 \%$ \\
\hline 50 years and above & 27 & $7.8 \%$ \\
\hline TOTAL & 348 & $100 \%-$ \\
\hline
\end{tabular}

The table above showed that respondents aged $15-19$ years stood at thirty (30) representing $8.6 \%$. Those within the ages of 20 - 24 years stood at thirty nine (39) or $11.2 \%$. Forty six (46) respondents representing $13.2 \%$ were aged between 25 29 years. Respondents within the ages Df 30 - 34 years stood at sixty seven (67) or $19.3 \%$. Respondents within the ages of 35 - 39 years stood at fifty nine (59) or $17 \%$. Respondents within the ages of $40-44$ years stood at thirty eight (38) or $10.9 \%$. Forty two (42) respondents representing $12 \%$ were aged between 45 - 49 years. Those aged 50 years and above stood at twenty seven (27) or $7.8 \%$. The bar chart above showed that eighty seven (87) respondents were single. Fifty five (55) respondents were married. Sixty one (61) respondents were divorced. Forty nine (49) respondents were widows. Sixty seven (67) respondents were widowers.

Pie Chart Showing Educational Background of Respondents.

The pie chart above showed that $90\left(93^{\circ}\right)$ of the respondents had no formal education. 83 $\left(86^{\circ}\right)$ respondents had primary education. 59 $\left(61^{\circ}\right)$ respondents had tertiary education. 116 $\left(120^{\circ}\right)$ respondents had secondary education.

Fig 2:

TABLE 3: Length of Stay in the Prison.

\begin{tabular}{|l|l|l|}
\hline OPTION & RESPONDENTS & PERCENTAGE \\
\hline Less than 1 year & 50 & $14.4 \%$ \\
\hline $1-5$ yrs & 64 & $18.4 \%$ \\
\hline $6-10$ yrs & 49 & $14.1 \%$ \\
\hline $11-15$ yrs & 68 & $19.5 \%$ \\
\hline $16-20 y r s$ & 47 & $13.5 \%$ \\
\hline $21-25$ yrs & 39 & $11.2 \%$ \\
\hline 26 years and above & 31 & $8.9 \%$ \\
\hline TOTAL & 348 & $100 \%$ \\
\hline
\end{tabular}


The table above reveals that 50 respondents representing $14.4 \%$ had spent less than 1 year in the prison. $64(17.4 \%)$ respondents had spent between 1-5 years. 49 respondents representing $14.1 \%$ had spent between 6-10 years in the prison. 68 respondents representing $18.5 \%$ had spent between 11-15 years. 47 respondents representing 15.5\% had spent between 16 - 20 years in the prison. 39 respondents representing $11.2 \%$ had spent between $21-25$ years in the prison. 31 respondents representing $8.9 \%$ had spent about 26 years and above in the prison.

Pie Chart Showing Categories of Prisoners.

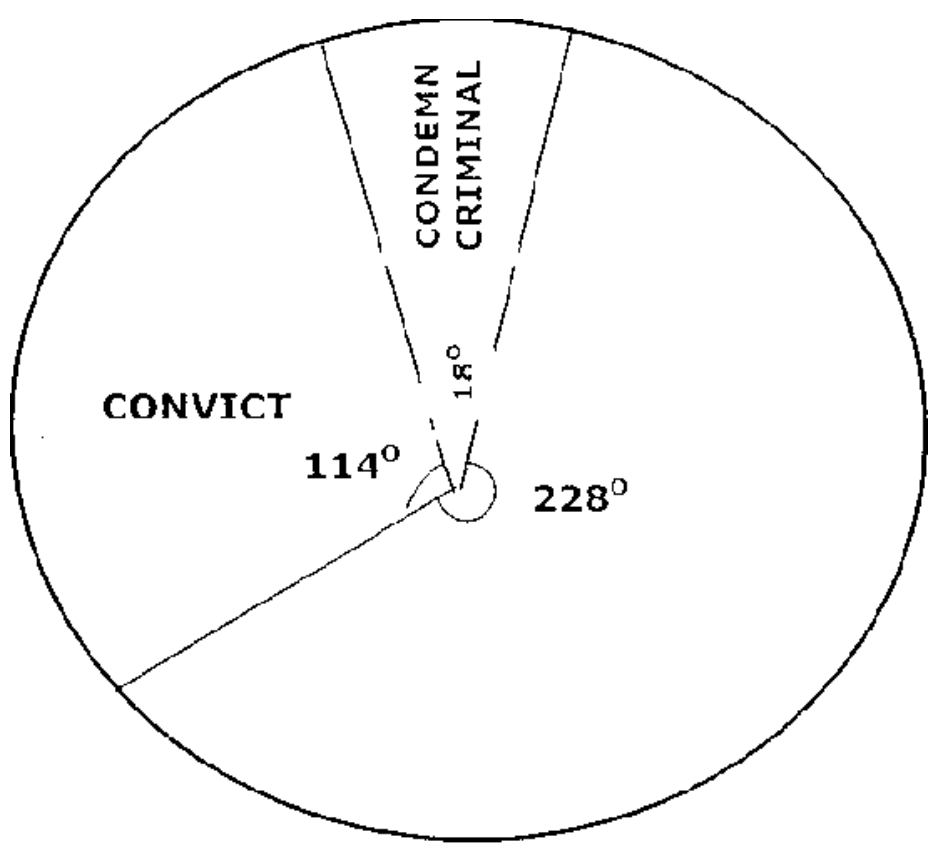

\section{AWAITING TRIAL}

\section{Fig 3:}

The pie chart above showed that out of the total respondents, 220 respondents representing $228^{\circ}$ were jawaiting trial prisoners. Ill respondents representing $114^{\circ}$ iv/ere convicts while 17 respondents representing $18^{\circ}$ were condemn criminals.

TESTING OF HYPOTHESIS I:

H0: Low level knowledge among inmates of Port Harcourt prison is not related to the prevalence of scabies. h1: Low level knowledge among inmates of Port Harcourt prison is related to the prevalence of scabies.

To test this hypothesis, the following questions were asked:

Question 7: Prison inmates are sufficiently educated on the

behaviour of scabies. 
TABLE 4:

\begin{tabular}{|l|l|l|}
\hline OPTION & RESPONDENTS & PERCENTAGE \\
\hline Strongly Agree & 50 & $14.4 \%$ \\
\hline ! Agree & 48 & $13.6 \%$ \\
\hline Disagree & 119 & $34.4 \%$ \\
\hline Strongly Disagree & 131 & $37.6 \%$ \\
\hline TOTAL & 348 & $100 \%$ \\
\hline
\end{tabular}

The table above showed that fifty (50) respondents representing $14.4 \%$ strongly agreed that prison inmates are sufficiently educated on the behavior of scabies. Forty eight (.48) respondents agreed. One hundred and nineteen (119) respondents or $34.4 \%$ disagreed. One hundred and thirty one (131) respondents strongly disagreed.

Question 8: Scabies is a parasitic infestation of the skin that spreads in form of crusts and itches. TABLE 5:

\begin{tabular}{|l|l|l|}
\hline OPTION & RESPONDENTS & PERCENTAGE \\
\hline Strongly Agree & 58 & $16.6 \%$ \\
\hline Agree & 50 & $14.4 \%$ \\
\hline Strongly Disagree & 67 & $19.3 \%$ \\
\hline Disagree & 173 & $49.7 \%$ \\
\hline TOTAL & 348 & $100 \%$ \\
\hline
\end{tabular}

From the table above, it could be inferred that 58

*

(16.6\%) strongly agreed that scabies is a parasitic infestation of the skin that spreads in form of crusts and itches. 50 (14.4\%) respondents agreed. $67(19.3 \%)$ respondents strongly disagreed. $173(49.7 \%)$ respondents disagreed.

Question 9: Which of these is true of scabies.

TABLE 6:

\begin{tabular}{|l|l|l|}
\hline OPTION & RESPONDENTS & PERCENTAGE \\
\hline A disease of the skin & 150 & $43 \%$ \\
\hline A disease of the intestine & 98 & $28 \%$ \\
\hline A disease of the heart & 100 & $29 \%$ \\
\hline TOTAL & 348 & $100 \%$ \\
\hline
\end{tabular}

The table above showed that 150 (43\%) indicated that scabies is a disease of the skin. $98(28 \%)$ said that scabies a disease of the intestine. $100(29 \%)$ were of the view lat scabies is a disease of the heart.

Question 10: Scabies spread through skin contact.
Fifty nine (59) respondents agreed. One hundred and eight (118) respondents strongly disagreed. Ninety one (91) respondents disagreed.

Question 11: Are inmates thought the causes of scabies. 
TABLE 7:

\begin{tabular}{|l|l|l|}
\hline OPTION & RESPONDENTS & PERCENTAGE \\
\hline Yes & 68 & $20 \%$ \\
\hline No & 280 & $80 \%$ \\
\hline TOTAL & 348 & $100 \%$ \\
\hline
\end{tabular}

The table above showed that 68 respondents representing $20 \%$ indicated that inmates of the prison are thought the cause of scabies. 280 respondents representing $80 \%$ indicated that inmates of the prison are not thought the causes of scabies. Seventy nine (79) respondents indicated that resource persons from outside provide them with knowledge on scabies. Fifty four (54) respondents indicated that prison publications provide them with knowledge on scabies. Sixty one (61) respondents indicated that fellow inmates constitute their source of knowledge on scabies.

Question 13: What is the level of publicity given to the causes of scabies.

TABLE 8

\begin{tabular}{|l|l|l|}
\hline OPTION & RESPONDENTS & PERCENTAGE \\
\hline High Publicity & 44 & $13 \%$ \\
\hline Average Publicity & 77 & $22 \%$ \\
\hline Low Publicity & 189 & $54 \%$ \\
\hline No Publicity & 38 & $11 \%$ \\
\hline TOTAL & 348 & $100 \%$ \\
\hline
\end{tabular}

The table above showed that forty four (44) respondents representing $13 \%$ indicated that causes of scabies receives high publicity in the prison. Seventy seven (77) respondents or $22 \%$ indicated that causes of scabies receives average publicity in the prison. One hundred and eighty nine (189)(respondents representing $54 \%$ indicated that causes of scabies receives low publicity in the prison. Thirty eight (38) respondents or $11 \%$ indicated that causes of scabies receives no publicity in the prison.

Question 14: Which of these represents the level of [knowledge of inmates on scabies. TABLE 9:

\begin{tabular}{|l|l|l|}
\hline OPTION & RESPONDENTS & PERCENTAGE \\
\hline High & 47 & $14 \%$ \\
\hline Average & 70 & $20 \%$ \\
\hline Low & 231 & $66 \%$ \\
\hline TOTAL & 348 & $100 \%$ \\
\hline
\end{tabular}

The table above showed that forty seven (47) respondents or $14 \%$ indicated that the level of knowledge of the inmates on scabies is high. Seventy (70) respondents or \% indicated that the level of knowledge of inmates on scabies is on the average. Two hundred and thirty one (231) respondents representing $66 \%$ indicated that the level of :nowledge of inmates on scabies is low. 
NOTE: Values from question 14 is used to test hypotheses I.

\begin{tabular}{|l|l|l|l|l|l|}
\hline OPTION & O & E & O - E & $(0-E) 2$ & Fo [In \\
\hline High & 47 & 116 & -69 & 4761 & 41.0 \\
\hline Average & 70 & 116 & -46 & 2116 & 18.2 \\
\hline Low & 231 & 116 & 115 & 13225. & 114.0 \\
\hline TOTAL & 348 & 348 & & & 173.2 \\
\hline
\end{tabular}

Hence, the calculated X2 = 173.2 "the degree of freedom $\mathrm{df}=\mathrm{k}-1,=$ Hence $3-1$ st a 0.05 , df - 2, Cal X2 = 173.2, Tab X2 - 5.99

Decision Rule accept Ho if cal X2 < Tab X2 Reject Ho if cal X2 > Tab X2

\section{Decision}

Since the calculated X2 (173.2) is greater then the tabulated X2 (5.99), we reject H0 and accept hi which states that low level knowledge among inmates of Port Harcourt prison is related to the prevalence of scabies.

\section{TESTING OF HYPOTHESIS II:}

H0: There is no relationship between restricted environment and occurrence of scabies.

$\mathrm{H} 2$ : There is a relationship between restricted environment and occurrence of scabies.

In order to test hypothesis II, the following questions were used:

Question 15: Have you been sick?

TABLE 10:

\begin{tabular}{|l|l|l|}
\hline OPTION & RESPONDENTS & PERCENTAGE \\
\hline Yes & 307 & $82 \%$ \\
\hline No & 41 & $18 \%$ \\
\hline TOTAL & 348 & $100 \%$ \\
\hline
\end{tabular}

The table above showed that three hundred and seven (307) respondents representing $82 \%$ indicated that they had ever been sick.

Question 16: Have you suffered from scabies.

TABLE 11:
Forty one (41) respondents representing $18 \%$ had a contrary submission.

\begin{tabular}{|l|l|l|}
\hline OPTION & RESPONDENTS & PERCENTAGE \\
\hline Yes & 243 & $70 \%$ \\
\hline No & 105 & $30 \%$ \\
\hline TOTAL & 348 & $100 \%$. \\
\hline
\end{tabular}

The table above showed that two hundred and forty three (243) respondents representing $70 \%$ indicated that $y$ had suffered from scabies. One hundred and five (105) respondents or $30 \%$ said they have not suffered from scabies attack. 
The bar chart above showed that 240 respondents were of the view that Portharcourt prison is restricted. 108 respondents had the view that the prison is unrestricted.

Question 18: Is Portharcourt prison well ventilated. TABLE 12:

\begin{tabular}{|l|l|l|}
\hline OPTION & RESPONDENTS & PERCENTAGE \\
\hline Yes & 119 & $34 \%$ \\
\hline No & 229 & $66 \%$ \\
\hline TOTAL & 348 & $100 \%$ \\
\hline
\end{tabular}

Question 19: Do you freely move around in the prison environment without restriction.

TABLE 13:

\begin{tabular}{|l|l|l|}
\hline OPTION & RESPONDENTS & PERCENTAGE \\
\hline Not at all & 75 & $21 \%$ \\
\hline A few times & 197 & $57 \%$ \\
\hline Most of the time & 41 & $12 \%$ \\
\hline All of the time & 35 & $10 \%$ \\
\hline
\end{tabular}

The table above showed that 75 respondents I representing $21 \%$ indicated that they do not freely move around in the prison environment at all. Majority numbering 197 or $57 \%$ indicated that they feely move around in the prison environment a few times. 41 respondents or $12 \%$ indicated that they freely move around in the prison environment most of the time.

Question 20: Does the physical structures within and around Portharcourt prison contribute to the prevalence of scabies among inmates.

TABLE 14:

\begin{tabular}{|l|l|l|}
\hline OPTION & RESPONDENTS & PERCENTAGE \\
\hline Yes & 258 & $74 \%$ \\
\hline No & 90 & $26 \%$ \\
\hline TOTAL & 348 & $100 \%$ \\
\hline
\end{tabular}

The table above showed that two hundred and fifty eight (258) respondents representing $74 \%$ indicated that the physical structures within and around Portharcourt prison contribute to the prevalence of scabies among inmates. Ninety (90) respondents representing $26 \%$ had a contrary view.

NOTE: Values from question 20 is used to test hypothesis II.

\begin{tabular}{|l|l|l|l|l|l|}
\hline OPTION & O & E & O - E & $(0-E) 2$ & ro-Fi2 \\
\hline Yes & 258 & 174 & 84 & 7056 & 40.6 \\
\hline$!$ No I & 90 & 174 & -84 & 7056 & 40.6 \\
\hline TOTAL & 348 & 348 & & & 81.2 \\
\hline
\end{tabular}


Hence, the calculated $\mathrm{X} 2=81.2$

(The degree of freedom $\mathrm{df}=\mathrm{k}-1=$ Hence 2 $1=1$

I At a $0.05, \mathrm{df}=1, \mathrm{Cal} \mathrm{X} 2=81.2, \mathrm{Tab} \mathrm{X} 2=$ 3.84

Decision Rule

i Accept Ho if Cal X2 < Tab X2 Reject Ho if

Cal X2 > Tab X2.

Decision

Since the calculated X2 (81.2) is greater than the tabulated X2 (3.84), we therefore reject
Ho and accept $\mathrm{H} 2$ which states that there is a relationship between restricted environment and occurrence of scabies.

\section{TESTING OF HYPOTHESIS III}

Ho: Overcrowding is not related to the attack rate of scabies.

H3: Overcrowding is related to the attack rate of scabies. In order to test hypothesis III, the following questions were asked:

Question 21: Which of these applies to Portharcourt prison in terms of overcrowding.

TABLE 15:

\begin{tabular}{|l|l|l|}
\hline OPTION & RESPONDENTS & PERCENTAGE \\
\hline Fairly Overcrowded & 59 & $17 \%$ \\
\hline Overcrowded & 111 & $32 \%$ \\
\hline Heavily Overcrowded & 178 & $51 \%$ \\
\hline TOTAL & 348 & $100 \%$ \\
\hline
\end{tabular}

The table above showed that fifty nine (59) respondents or $17 \%$ rated Portharcourt prison as being fairly overcrowded. One hundred and eleven (111) respondents or $32 \%$ indicated that the prison is overcrowded. Majority numbering one hundred and seventy eight (178) or $51 \%$ indicated that Portharcourt prison is heavily overcrowded. Question 22: Are there enough bed spaces for inmates.

table 16:

\begin{tabular}{l|c|c|}
\hline OPTION & \multicolumn{2}{c}{ PERCENTAGE } \\
Yes & 33 & $9 \%$ \\
\hline No & 315 & $91 \%$ \\
\hline TOTA & $\mathbf{3 4 8}$ & $\mathbf{1 0 0 \%}$ \\
\hline
\end{tabular}

The table above reveals that thirty three (33) respondents representing 9\% indicated that there are enough bed spaces for inmates. Majority numbering three hundred and fifteen (315) or 91\% had a contrary view.

Question 23: Where do you sleep.

Question 24: How would you assess the spread of scabies among inmates of Portharcourt prison. 
TABLE 17:

\begin{tabular}{|l|l|l|}
\hline OPTION & RESPONDENTS & PERCENTAGE \\
\hline Slow & 38 & $11 \%$ \\
\hline Fairly Fast & 95 & $27 \%$ \\
\hline Past & 100 & $29 \%$ \\
\hline Very Fast & 115 & $33 \%$ \\
\hline TOTAL & 348 & $100 \%$ \\
\hline
\end{tabular}

The table above showed that 38 respondents representing $11 \%$ indicated that scabies spread slowly among inmates in Portharcourt prison. 95 respondents or 275 indicated that the spread of scabies among inmates of portharcourt prison is rather fairly fast. 100 respondents representing 29\% indicated that the spread is fast. 115 respondents representing 33\% indicated that the spread is very fast.

Question 25: Are scabies patients isolated.

TABLE 18:

\begin{tabular}{|l|l|l|}
\hline OPTION & RESPONDENTS & PERCENTAGE \\
\hline Yes & 57 & $16 \%$ \\
\hline No & 291 & $84 \%$ \\
\hline TOTAL & 348 & $100 \%$ \\
\hline
\end{tabular}

From the table above, it could be inferred that 57 respondents representing 16\% indicated that scabies patients are isolated.
291 respondents representing 84\% indicated that scabies patients are not isolated.

Question 26: Overcrowding is responsible for the rate at which scabies multiplies among inmates of Porthrarcourt prison.

TABLE 19:

\begin{tabular}{|l|l|l|}
\hline OPTION & RESPONDENTS & PERCENTAGE \\
\hline Strongly Agree & 135 & $39 \%$ \\
\hline Agree & 93 & $27 \%$ \\
\hline Disagree & 71 & $20 \%$ \\
\hline Strongly Disagree & 49 & $14 \%$ \\
\hline TOTAL & 348 & $100 \%$ \\
\hline
\end{tabular}

The table above showed that 135 respondents representing $39 \%$ strongly agreed that overcrowding is responsible for the rate at which scabies multiplies among inmates of Portharcourt prison. 93 respondents or $27 \%$ agreed. 71 respondents or $20 \%$ disagreed 49 respondents or $14 \%$ strongly disagreed. 
NOTE: Values from question 26 is used to test hypothesis

III.

\begin{tabular}{|l|l|l|l|l|l|}
\hline OPTION & $\mathrm{O}$ & $\mathrm{E}$ & $\mathrm{O}-\mathrm{E}$ & $(0-\mathrm{E}) 2$ & F E) \\
\hline Strongly Agree & 135 & 87 & 48 & 2304 & 26.5 \\
\hline Agree & 93 & 87 & 6 & 36 & 0.4 \\
\hline Disagree & 71 & 87 & -16 & 256 & 3.0 \\
\hline Strongly Disagree & 49 & 87 & -38 & 1444 & 16.6 \\
\hline TOTAL & 348 & 348 & & & 46.5 \\
\hline
\end{tabular}

Hence the calculated $X=46.5$

The degree of freedom $\mathrm{df}=\mathrm{k}-1=$ Hence $4-1=3$ at $0.05, \mathrm{df}=3$, Cal X2 -46.5 , Tab $\mathrm{X} 2=7.82$

Decision Rule

Accept Ho if Cal X2 < Tab X Reject Ho if

Cal X2 > Tab X

Decision

Since the calculated X2 (46.5) is greater than the tabulated X2 (7.82), we therefore reject $\mathrm{Ho}$ and accept $\mathrm{H} 3$ which states that overcrowding is related to the attack rate

\section{TESTING OF HYPOTHESIS IV}

Ho: Self care among inmates of Portharcourt prison is pot related to persistence of scabies. H4: Self care among inmates of Portharcourt prison is related to persistence of scabies. To test the hypothesis, the following questions were asked: of scabies.

Question 27: Do you have clinic within the prison.

TABLE 20:

\begin{tabular}{|l|l|l|}
\hline OPTION & RESPONDENTS & PERCENTAGE \\
\hline Yes & 327 & $94 \%$ \\
\hline No & 21 & $6 \%$ \\
\hline TOTAL & 348 & $100 \%$ \\
\hline
\end{tabular}

The table above showed that majority of the respondents numbering 327 or $94 \%$ indicated that there exist clinic within the prison environment. 21 respondents representing $6 \%$ had a contrary view.

Question 28: Do you have enough doctors and nurses.

TABLE 21:

\begin{tabular}{|l|l|l|}
\hline OPTION & RESPONDENTS & $\begin{array}{l}\text { PERCENTAGE } \\
i_{i}\end{array}$ \\
\hline Yes & 99 & $28 \%$ \\
\hline No & 249 & $72 \%$ \\
\hline TOTAL & 348 & $100 \%$ \\
\hline
\end{tabular}


The table above showed that 99 respondents representing $28 \%$ indicated that the prison does not have enough

TABLE 22: doctors and nurses. Majority numbering 249 or $72 \%$ had a contrary view.

Question 29: Do you have enough drugs in your clinic.

\begin{tabular}{|l|l|l|}
\hline OPTION & RESPONDENTS & PERCENTAGE \\
\hline Yes & 32 & $8 \%$ \\
\hline No & 316 & $92 \%$ \\
\hline TOTAL & 348 & $100 \%$ \\
\hline
\end{tabular}

The table above showed that 32 respondents representing $8 \%$ indicated that they have enough drugs in the clinic. contrary view.

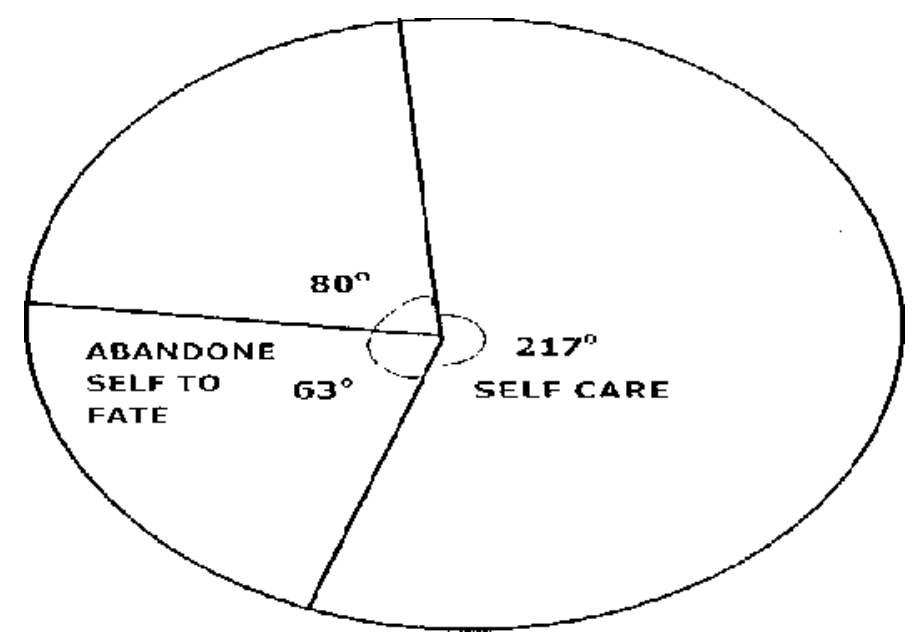

VISIT THE CLINIC

Pie chart showing measures accepted by the inmates when they fall sick.

Fig 8:

The pie chart above shows that 210 respondents representing $217^{\circ}$ indicated that they adopt self care when they fall sick. 77 respondents or $80^{\circ}$ indicated that they visit the clinic. 61 respondents representing $63^{\circ}$ indicated that they abandone self to fate when they fall sick.

Question 31: Is self care common among inmates of Portharcourt prison.

TABLE 23:

\begin{tabular}{|l|l|l|}
\hline OPTION & RESPONDENTS & PERCENTAGE \\
\hline Yes & 322 & $93 \%$ \\
\hline No. & 26 & $7 \%$ \\
\hline TOTAL & 348 & $100 \%$ \\
\hline
\end{tabular}


The table above showed that 322 respondents representing 93\% indicated that self care is common among inmates of Portharcourt prison.
26 respondents representing $7 \%$ had a contrary view.

Question 32: The frequency of self care among inmates is related to the persistence of scabies in the prison.

TABLE 24:

\begin{tabular}{|l|l|l|}
\hline OPTION & RESPONDENTS & PERCENTAGE \\
\hline Strongly Agree & 167 & $48 \%$ \\
\hline Agree & 118 & $34 \%$ \\
\hline Disagree & 34 & $10 \%$ \\
\hline Strongly Disagree & 29 & $8 \%$ \\
\hline TOTAL & 348 & $100 \%$ \\
\hline
\end{tabular}

The table above showed that 167 respondents representing $48 \%$ strongly agreed that the frequency of self care among inmates is related to

the persistence of scabies in the prison. 118 respondents representing 34\% agreed, 34 respondents or $10 \%$ disagreed. 29 respondents or $8 \%$ strongly disagreed.

NOTE: Values from question 32 is used to test hypothesis

\begin{tabular}{|l|l|l|l|l|l|}
\hline OPTION & O & E & O - E & $(0-$ E)2 & CO- El2 \\
\hline Strongly Agree & 167 & 87 & 80 & 6400 & E \\
\hline Agree & 118 & 87 & -31 & 961 & $\begin{array}{l}11.1 \\
1\end{array}$ \\
\hline Disagree & 34 & 87 & -53 & 2806 & 32.3 \\
\hline Strongly Disagree & 29 & 87 & -58 & 3364 & 38.7 \\
\hline TOTAL & 348 & 348 & & & 155.7 \\
\hline
\end{tabular}

Hence, the calculated X2 $=155.7$

The degree of freedom df $=\mathrm{k}-1=$ Hence $4-1=3$ At a 0.05, df - 3, Cal X2 - 155.7, Tab X2 - 7.82

Decision Rule

Accept Ho if Cal X2 < Tab X2 Reject Ho if Cal $\mathrm{X} 2>\mathrm{Tab} \mathrm{X} 2$.

Decision

Since the calculated X2 (155.7) is greater than the tabulated X2 (7.82), we therefore reject Ho and accept H4 (which states that self care among inmates of Portharcourt prison is related to persistence of scabies.

\section{Discussion}

The study examined the nature of Portharcourt prison vis-a-vis the prevalence of scabies among inmates.
Findings from the study show a low level of knowledge among inmates. The inmates are not sufficiently educated on the aetiology of scabies. Such low level of knowledge among inmates was found to contribute to a larger extent towards the spread and persistence of the disease in the prison.Most of the inmates of the prison were found to have suffered from scabies.

Portharcourt prison is not well ventilated. Inmates rarely move freely within and round the prison environment owing to the restricted nature of the prison. Such a measure was found to contribute in no small measure towards the prevalence of scabies in the prison. 
Portharcourt prison was equally found to be highly congested. The level of overcrowding in Portharcourt prison has reached a level whereby most inmates sleep on the floor and with a reasonable number of inmates sharing beds. The situation is further aggravated by the non isolation of scabies patients. The net effect hence is the speedy spread of scabies among the inmates.

Findings also show that although Portharcourt prison has a clinic, the clinic is neither adequately staffed with enough medical personnel nor supplied with enough drugs. The absence of enough medical personnel as well as inadequate drugs supply forces most inmates to resort to self medication while others simply abandone self to fate thus further aggravating the prevalence of scabies in the prison.

\section{Conclusion}

The goal of reforming and rehabilitating Nigerian prisoners remains the dream of Nigerian government. However, such a drive towards transforming a societal deviant to a conformist cannot be realized unless Nigerian prisons are given a new face.

Scabies infection will continue feature of Nigerian prisons not until prompt steps are taken not only to decongest the prisons but to adjust some physical structures that strengthen scabies pandemic in the prisons. All that is therefore required is an active collaboration among the Government, the private sector as well as Non Governmental Organisations to make Nigerian (prisons scabies free.

\section{References}

Aimakho, K. (2010). Sexually Transmitted Diseases Training Manual for Medical Doctors at FMC Owerri. Unpublished.

international Alliance for the Control of Scabies (2014). About Scabies. http://www.control scabies.org/about scabies.

Keegan V.I. (2007). Research Methodology Owerri: Career publishers.

Sergio, V. (2008). The Clinical Picture of Scabies. Cleveland Journal of Medicine, 75(7) :474-478.

Tidy, C. (2013). Scabies, http://www.patient.co.uk/print/ 2990. Retrieved $17 / 1 / 2014$.

Uwaneme, R.C. (2011). The nature of institution and the prevalence of tuberculosis. A case of inmates of

PortHarcQurt Prison, Rivers State, Nigeria. Unpublished

PGDPH Thesis of Imo State University Nigeria.

\begin{tabular}{|c|l|}
\hline \multicolumn{2}{|c|}{ Access this Article in Online } \\
\hline Q & Website: \\
& www.ijcrims.com \\
\hline Quick Response Code & Subject: \\
\hline
\end{tabular}

\section{How to cite this article:}

Ozims,S.J.,Agu,G.C.,Nwosu,D.C.,Obeagu,E.I.,Amah,H.,Nwanjo,H.U.,Edward,Amaka and Izuchukwu,I.F. (2016). The nature of institution and the prevalence of scabies: a case study of inmates of Portharcourt prison of rivers state Nigeria. Int. J. Curr. Res. Med. Sci. 2(11): 11-26. DOI: http://dx.doi.org/10.22192/ijcrms.2016.02.11.002 